\title{
EUROPEANA FOR US: TRANSFORMING THE WESTERN BALKAN WITH CULTURE*
}

\author{
Tamara Butigan Vučaj \\ Načelnica Odeljenja za razvoj digitalne biblioteke, Narodna biblioteka Srbije, Beograd, Srbija \\ Head of Digital Library Development Department, National Library of Serbia, Belgrade, Serbia \\ Članica Saveta Evropeana mreže / Member of the Council of Europeana Network \\ tamara@nb.rs
}

\begin{abstract}
Europeana is the largest investment and project of the European Union when it comes to digitalization of cultural heritage. Although firmly connected to the European Union, Europeana is open to the non-EU part of Europe as well as to other continents, in an attempt to present as fully as possible a digital replica of the culture of the old continent. Serbia's experience in cooperation with Europeana has been recognized as a successful story and this paper could inspire other Western Balkan countries to be more active, and besides the benefits for institutions and individuals, it is obvious that it could fill the gaps when it comes to European cultural heritage.
\end{abstract}

Keywords: Europeana, digitization of cultural heritage, European projects, CEF Telecom financing program, Western Balkans

\section{Introduction}

Europeana is the largest investment and project of the European Union when it comes to digitalization of cultural heritage. For eleven full years, Europeana is growing: as a portal that provides access to over 57 million digital objects from over 3,500 cultural institutions, as a network of over 2,600 members and as a foundation with 30 employees, based in The Hague, at the Royal Library of the Netherlands. Although firmly connected to the European Union, Europeana is open to the non-EU part of Europe as well as to other continents, in an attempt to present as fully as possible a digital replica of the culture of the old continent as viral content, to be shared, used and reused, in the creative industries, in education, or simply for personal enjoyment.

For the countries of Western Balkans, the doors of Europeana are wide open. This attests the project Collections of South and Eastern Europe in Europeana, successfully implemented by the European Library (TEL) from September 2015 to December
2016. The project coordinator was the National and University Library in Zagreb, with partners: European Library (TEL), National Library of Albania, National and University Library of Bosnia and Herzegovina, National Library of Montenegro "Đurđe Crnojević", National and University Library "St. Kliment Ohridski", Northern Macedonia, National Library of Moldova, National and University Library, Slovenia and National Library of Serbia. In addition to the content that these national libraries have published on Europeana, some for the first time, a wonderful exhibition of old postcards from Southeastern Europe entitled: "Picture this!" is the added value of this project, https://www.europeana. $\mathrm{eu} / \mathrm{portal} / \mathrm{en} / \mathrm{exhibitions/picture-this-vintage-post-}$ cards-of-southeastern-europe.

The narrative of the exhibition emphasizes that this is a part of Europe where stones speak and where geography most often becomes history and vice versa. At the same time, this part of Europe is the least represented in Europeana and if we all push our own borders, it could be easily changed.

\footnotetext{
* Europeana motto is: We are transforming the world with a culture, that I have adapted for the geographical area of my paper $(\mathrm{A} / \mathrm{N})$.
} 


\section{Aggregator for Europeana at the National Library of Serbia}

The National Library of Serbia is one of the 3,500 cultural institutions that cooperate with Europeana, i.e., they have contents on its portal, as well as one of the 36 Europeana aggregators. Aggregator is an infrastructure for collecting, verifying and delivering metadata and as such provides support to $\mathrm{Eu}-$ ropeana in fulfilling its mission: "transforming the world with culture". However, the main objective of the aggregator is to support the cultural institutions for which it is responsible. National and regional aggregators mediate the delivery of digital content by cultural institutions of a country or region, such example is Slovenian national e-content aggregator in NUL, Ljubljana, http://www.agregator.si/, or CulturaItalia in The Central Institute for the Union Catalogue in Rome, http://www.culturaitalia.it/. Domain and thematic aggregators are tied to a specific cultural sector, to archives such as Archives Portal Europe, http://www.archivesportaleuropefoundation. $\mathrm{eu} /$, or to specific theme, such as European Fashion Heritage Association, https://fashionheritage.eu/.

The Europeana Aggregator Forum, established in 2012, takes care of the exchange of ideas, knowledge, experiences and best practices among the aggregators. The Forum brings together all the aggregators twice a year: in March it hosts the Europeans Foundation in The Hague, and in October, host is one of the aggregators. During 2018, in the spirit of democratization, Forum has attained a new management team from the ranks of the aggregators, who make Marco Rendina from European Fashion Heritage Association, Sara Di Giorgio from Central Institute for the Union Catalogue and Henning Scholz from Europeana.

As of 2018, the Forum awards accreditation to aggregators, as trusted partners. The Europeana Aggregator, which operates within the Digital Library Development Department of the National Library of Serbia, is the only European aggregator outside the European Union and has been accredited since March 2019.

The National Library of Serbia received support for the establishment of the Europeana Aggregator from the EU Delegation in the Republic of Serbia and the Ministry of Culture and Information of the Republic of Serbia. The technical partner of the National Library of Serbia, without whom this venture would not be possible, is the Slovenian IT company Semantika, which is a multi-year associate of Europeana on technical solutions.



Bruxelles-exposition: pavillon de Bosnie et Herzégovine, 1897, Ghent University Library, CC BY-SA ${ }^{1}$

\section{Projects with Europeana}

The National Library of Serbia is one of the 24 partners in institutions in the in Europeana ${ }^{2}$ Common Culture project, which aims to develop a well-coordinated environment for national aggregators so that they can collaborate, share resources and establish common recommendations and standards. This project will also increase the quality of content and metadata available on the Europana portal, in order to expand the range of users and ways of using the content. Project coordinator is Europeana Foundation, duration from January 2019 to June 2020 and is financially supported by the CEF Telecom ${ }^{3}$ European Program. The project brings together 24 partner institutions from 20 countries of the European Union and one country outside the European Union (Serbia). Among them seven national libraries from the following countries are included: Latvia, Lithuania, Germany, Portugal, Slovenia, Serbia and Finland, regional library from Varna, Bulgaria, there are Ministry of Culture and Sports of Spain, Ministry of Education and Sports of Cyprus, Estonian Libraries Network Consortium, Central Institute for the Union Catalogue of Italian Libraries, couple of universities: KU Leuven (Belgium), University for technology from Cyprus, University in Helsinki (Finland), Petöfi Literary Museum (Hungary), couple of foundations and institutions, as well as coordinating institution - Europeana Foundation.

Almost all partner institutions, 21 of them, are also national aggregators for Europeana. The project

\footnotetext{
Bosnia and Herzegovina Pavilion at the World Exhibition in Brussels 1897, taken from Europeana, https://www.europeana.eu/portal/en/record/9200229/BibliographicResource_3000135642195.html?q=bosnie\#dcld=1573635678283 $\& \mathrm{p}=1$.

2 Europeana Common Culture: https://pro.europeana.eu/ project/europeana-common-culture.

3 CEF Telecom - Connecting Europe Facility Telecom: https:// ec.europa.eu/inea/en/connecting-europe-facility/cef-telecom.
} 
also includes 8 associated partners, including all EU countries.

In addition to continuing work on enriching metadata and applying the principles of connected open data, through the Common Culture project, National library of Serbia has included in Europeana Digital collection of industrial heritage of Bor, ${ }^{4}$ as well as photographs of Sephardic family Kalef, ${ }^{5}$ and in the inclusion plans are Yugoslav journal Ženski pokret / Women's movement (1920-1938) and collection of photographs from Sisters Janković legacy. At the same time, publishing of the new content within the projects is accompanied by strong marketing activity, and so far, published gallery is "Rudnici i rudari", ${ }^{6}$ in which are featured photos from Bor, as well as the blog "Borski rudnik: rad i pejzaži tokom 20. veka"7 by author Saša Ilić.

Both contents were published as part of the Europeana autumn campaign Europe at Work. All contents were promoted on social networks and on the website of the National Library of Serbia.

The project Migration in the Arts and Sciences, ${ }^{8}$ inspired by recent migrations from the east, sought for sources to discover the extent to which migrations shaped contemporary European culture and science. The Europeana Foundation coordinated this project with the participation of 6 partner institutions: KU Leuven (Belgium), National Archives of Hungary, National Audiovisual Institute of Poland, The Netherlands Institute for Sound and Vision, National Library of Lithuania and National Library of Serbia. The project is funded by the CEF Telecom European program. The project was active from September 2017 to February 2019, and for the duration of the project a thematic collection on migration was formed in Europeana, ${ }^{9}$ to which all partners have added new content. This project was also followed by a number of blogs, galleries and exhibitions, and the National Library of Serbia participated with the following contents: Ljudi u pokretu, ${ }^{10}$ contribution

\footnotetext{
4 https://www.europeana.eu/portal/en/search?q=edm datasetName\%3A146*\&per_page=12\&view=grid.

5 https://www.europeana.eu/portal/en/ search?q=europeana_collectionName\%3A(145_ECC_NLSerbia_kalef)\&view=grid.

6 Mining and Miners: https://www.europeana.eu/portal/en/ explore/galleries/mining-and-miners.

7 The Bor Mine in Serbia: labour and landscape throughout the 20th century: https://blog.europeana.eu/2019/11/thebor-mine-in-serbia-labour-and-landscape-throughout-the20th-century/.

8 Migration in the Art and Science: https://pro.europeana.eu/ project/migration-in-the-arts-and-science.

9 https://www.europeana.eu/portal/en/collections/migration

${ }^{10} \mathrm{https} / / /$ www.europeana.eu/portal/en/exhibitions/peopleon-the-move
}

about Nikola Tesla, Miloš Crnjanski and contribution on holidays of Romani community in Serbia, in gallery Romi u Evropi ${ }^{11}$ with a selection of photographs from the Tihomir Đorđević legacy, while the blog Miloš Crnjanski: o lutalaštvu i jednoj autentičnoj egzistenciji ${ }^{12}$ is written by Milena Đorđijević.

Within the project, Migration Stories Collection Days were held on October 19 and 20 at the National Library of Serbia, https://www.nb.rs/events/ event.php?id=33889. On this occasion, 17 authentic stories of all kinds of migration were collected and all stories were included in Europeana. ${ }^{13} \mathrm{~A}$ whole series of events in collecting migration stories across Europe have been a contribution of Europeana and partner institutions to the European campaign: 2018 - European Year of Cultural Heritage.

The aim of the project Rise of Literacy ${ }^{14}$ was to provide insight into the use of the written word on the European continent from the 6th to the 20th century and to show the development of literacy in European culture. National and University Library, Slovenia was the coordinator for this project, which lasted from September 2017 to February 2019, and was funded by the CEF Telecom program. The partner institutions in the project were: Europeana Foundation, National Library of Greece, Royal Library of the Netherlands, National Library of Serbia, National Library of France, National Library of Scotland, National Library of Latvia, National Library of Portugal, Berlin State Library, Germany, Italian National Research Council - Opera del Vocabolario Italiano, Italy, Central Institute for the Union Catalogue, Italy, and National Library of Wales.

This project has greatly enriched Europeana content with handwritten material, old books, newspapers and journals, and a large number of blogs, galleries and two exhibitions have contributed to the promotion of new and old content, celebrating the written word and languages of the old continent. The National Library of Serbia has prepared a number of pending blogs, and during the campaign and Women's Month in March 2019, library has published a blog about Jelena Dimitrijević, ${ }^{15}$ written by Ana Stevanović.

\footnotetext{
${ }_{11}$ https://www.europeana.eu/portal/en/explore/galleries/romani-people-in-europe

12 https://blog.europeana.eu/2019/10/milos-crnjanski-a-literary-life-of-migration-and-exile/

${ }^{13}$ https://www.europeana.eu/portal/en/ search? locale=en\&per_page $=48 \& q=$ proxy_dcterms_isPa rtOf\%3A\%22Europeana+Migration+collection+day\%2C+ Belgrade $\% 2 C+$ National+Library+of+Serbia\%2C+2018-1019\%E2\%80\%932018-10-20\%22\&view=grid

${ }^{14}$ Rise of Litearcy: https://pro.europeana.eu/project/rise-ofliteracy.

${ }^{15}$ https://blog.europeana.eu/2019/03/the-trailblazer-jelenadimitrijevic-serbias-first-feminist-author/
} 
In addition to the obvious benefits of financial support in digitization and adoption of metadata standards and its aggregation, projects with Europeana brings more when it comes to class education. For the National Library of Serbia, one of the most important was how to promote digital collections through blogs, exhibitions and galleries. And the lesson on copyright for digital objects is invaluable in an environment where there is little experience with copyright in the digital world. After experience in two projects, experts of the National Library of Serbia with much more confidence implement Creative Commons licenses for digital objects that are published online.

\section{How to get involved in Europeana}

The Europeana Network is certainly the first step towards more intensive cooperation, https://pro.europeana.eu/network-association. The Network is managed by a 36 -member Council, of which a 6 -member Board of Directors is elected. Applying is quite easy, filling out the online form on web page: https://pro. europeana.eu/network-association/sign-up.

Network members' activities are channelled through 6 communities and gathered around 6 major topics: research, education, influence, copyright, communications and IT. The network is an open and democratic structure that, in November 2019, has exactly 2,625 members from all sectors of culture, educational and research institutions, the IT community and independent experts from all European countries and from other continents. The Western Balkan countries together have 107 members in the network, which is a potential force for more intensive cooperation.

At the end of each year, in November or December, Europeana organizes a large meeting of all network members, and this year, for the first time, in 2019, it organizes a three-day conference in Lisbon. All members of the network can apply, but due to the limited number of seats, only a certain number of members can attend, usually around 300 .

Europeana's annual event is a holiday for all that love and cooperate with Europeana. It is an opportunity to present new directions of development, to show results in what has already been done, but also to bring people together and agree on some future cooperation.

\section{Conclusion}

For the Western Balkan countries, cooperation with Europeana represents European integration in the field of digitization of cultural heritage. Europeana is not only a showcase for presenting the most valuable cultural heritage, it educates, not only in the field of metadata, but also in the technical aspects of digitalisation, and in the field of cultural heritage promotion, which is generally missing in our countries.

All members of the Europeana Network could act as ambassadors of the Europeana, both in their institutions, on social networks, and with their decision makers.

The support of the state, i.e. the line ministry, is more than welcome in order to achieve full cooperation. The example of Serbia may inspire in this case.

\section{Sources}

- Archives Portal Europe Foundation. http://www.archivesportaleuropefoundation.eu/

- The Bor Mine in Serbia: labour and landscape throughout the 20th century. https://blog.europeana. eu/2019/11/the-bor-mine-in-serbia-labour-and-landscape-throughout-the-20th-century/.

- Bruxelles-exposition: pavillon de Bosnie et Herzégovine. https://www.europeana.eu/ portal/en/record/9200229/BibliographicResource_3000135642195.html?q=bosnie\#dcId=157 $3635678283 \& \mathrm{p}=1$.

- CEF Telecom - Connecting Europe Facility Telecom. https://ec.europa.eu/inea/en/connecting-europe-facility/cef-telecom.

- Cultura Italia: l'aggregatore nazionale del patrimonio culturale italiano. http://www.culturaitalia.it/.

- Dani prikupljanja priča o migracijama. https://www. nb.rs/events/event.php?id=33889.

- Digital collection of industrial heritage of Bor. https://www.europeana.eu/portal/en/search?q=edm datasetName\%3A146*\&per_page=12\&view=grid

- Digital collection of Sephardic family Kalef. https:// www.europeana.eu/portal/en/search?q=europeana collectionName\%3A(145_ECC_NLSerbia_ kalef)\&view=grid.

- European Fashion Heritage Association. https:// fashionheritage.eu/.

- Europeana Common Culture. https://pro.europeana. eu/project/europeana-common-culture.

- Europeana Network Association. https://pro.europeana.eu/network-association.

- Join us. Europeana Network Association. https://pro. europeana.eu/network-association/sign-up. 
- Migration. https://www.europeana.eu/portal/en/collections/migration.

- Migration in the Art and Science. https://pro.europeana.eu/project/migration-in-the-arts-and-science.

- Migration Stories Collection Days in Serbia. https:// www.europeana.eu/portal/en/search?locale=en\&per page $=48 \& q=$ proxy_dcterms_isPartOf $\% 3 \mathrm{~A} \% 22 \mathrm{Eu}$ ropeana+Migration + collection + day $\% 2 \mathrm{C}+$ Belgrade $\% 2 \mathrm{C}+$ National+Library+of+Serbia $\% 2 \mathrm{C}+2018-10$ 19\%E2\%80\%932018-10-20\%22\&view=grid.

- Miloš Crnjanski: a literary life of migration and exile. https://blog.europeana.eu/2019/10/milos-crnjanski-a-literary-life-of-migration-and-exile/.

- Mining and Miners. https://www.europeana.eu/portal/en/explore/galleries/mining-and-miners.

- Nacionalni agregator e-vsebin. http://www.agregator.si/.

- People on the move. https://www.europeana.eu/portal/en/exhibitions/people-on-the-move.
- $\quad$ Picture this! Vintage postcards of Southeastern Europe. https://www.europeana.eu/portal/en/exhibitions/picture-this-vintage-postcards-of-southeastern-europe.

- Rise of Litearcy. https://pro.europeana.eu/project/ rise-of-literacy.

- Romani people in Europe. https:/www.europeana. eu/portal/en/explore/galleries/romani-people-ineurope.

- The Trailblazer: Jelena Dimitrijević, Serbia's first feminist author. https://blog.europeana.eu/2019/03/ the-trailblazer-jelena-dimitrijevic-serbias-first-feminist-author/.

\section{EVROPEANA ZA NAS: TRANSFORMIŠEMO ZAPADNI BALKAN KULTUROM}

\section{Sažetak}

Evropeana je najveća investicija i projekat Evropske unije kada je u pitanju digitalizacija kulturnog nasleđa. lako čvrsto vezana za Evropsku uniju, Evropeana je otvorena i prema delu Evrope koji nije u EU, ali i prema drugim kontinentima, u pokušaju da što sveobuhvatnije prikaže digitalnu repliku kulture starog kontinenta. Iskustvo Srbije u saradnji sa Evropeanom prepoznato je kao uspešna priča i ovaj rad bi mogao da inspiriše ostale zemlje zapadnog Balkana da budu aktivnije, a pored koristi za institucije i pojedince, nesporno je popunjavanje praznih polja u mozaiku evropskog kulturnog nasleđa.

Ključne reči: Evropeana, digitalizacija kulturnog nasleđa, evropski projekti, program finansiranja CEF Telecom, zapadni Balkan 